\title{
Managing Inventory on Blood Supply Chain
}

\author{
Fitra Lestari, Ulfah, Ngestu Nugraha and Budi Azwar
}

\begin{abstract}
There is unbalance the amount of blood demand and the availability of blood for each component at Blood Transfusion Unit in Indonesia. As the result, this component run into inventory shortage so management need to maintain the strategy of blood supply chain for the patients. Purpose of this is to manage inventory on the blood component of Packed Red Cells which it to be the highest blood component requirement for patient in this case study. Managing inventory is done through several stages including forecasting method, safety stock, and re-order point. Finding of this study was obtained that exponential smoothing $(\alpha=0.95)$ to be the best forecasting method. Then, to manage inventory, this agency need to prepared 34 blood bags for safety stock and 76 blood bags for re-order point. This results able to give recommendation to the Blood Transfusion Unit at Indonesia regarding with the number of blood component provided and how much re-order to be made at the time of reaching the lead time. Further study is suggested to conduct simulation method in order to evaluate policy in managing blood inventory and prepare scenario for optimizing inventory level.
\end{abstract}

Keywords Blood $\cdot$ Blood transfusion unit $\cdot$ Inventory $\cdot$ Production Re-order point $\cdot$ Safety stock $\cdot$ Supply chain

\footnotetext{
F. Lestari $(\varangle) \cdot$ N. Nugraha

Industrial Engineering Department, Sultan Syarif Kasim State Islamic University, Pekanbaru, Indonesia

e-mail: fitra_lestari@yahoo.com

N. Nugraha

e-mail: ngestu.nugraha@yahoo.com

Ulfah

AlMadinah Health Consulting in Indonesia, Pekanbaru, Indonesia

e-mail: ul_pha7@yahoo.com

B. Azwar

Islamic Economic Department, Sultan Syarif Kasim State Islamic University,

Pekanbaru, Indonesia

e-mail: budiazwar79@yahoo.com
} 


\section{Introduction}

Blood Transfusion Unit (BTU) serves to ensure the availability of blood, quality, safety, and blood donor information. To improve this services, the agency seeks to provide integrated information related with the blood supply activities for the patients. Blood deserved to be donated for the patient was blood that passed the screening test and fitting with the patient's blood [1]. In addition, BTU collaborates with various entities in conducting activities of blood donation involving donors, blood processing centers, hospitals and patients. For more details, the interrelation of activities among entities at BTU is to receive blood supplies from donors which it is transferred in form of blood bags. Then, blood is processed in BTU in order to determine the blood components and its quality. It aims to provide blood for patients infected with the virus or disease. Furthermore, the blood component that has been provided will be distributed to the patients. Obviously, the activity of blood distribution from donors to patients in form a flow of product which it can be studied based on supply chain strategy. Lestari et al. [2] revealed that the supply chain strategy is the integration of activities including several entities to provide the best service to the end consumer.

Moreover, this research conducted a case study at Blood Transfusion Unit in Indonesia. They provided seven blood components that were distributed to the patient involving whole blood, packed red cell, thrombocyte concentrate, fresh frozen plasma, washed erytrocyte, cryoprecipitate and apheresis [3]. Data of blood demand at BTU in years 2016 showed that there was unbalance the amount of blood demand and the availability of blood for each component which this can be seen in Table 1 . The results in this table found that the highest blood component requirement for patient is Packed Red Cell (PRC). Furthermore, this component run into inventory shortage; as the result, management needed to maintain the strategy of blood supply chain for the patients. Thus, the main problem in this research is the unbalance of the amount of blood supply with the amount of blood demand. Consequently, it showed that the number of donors over time decreases while the demand for blood products tends to increase.

Table 1 Demand and supply of blood component

\begin{tabular}{l|l|l|l}
\hline Blood component & $\begin{array}{l}\text { Average monthly } \\
\text { demand (bag) }\end{array}$ & $\begin{array}{l}\text { Average monthly } \\
\text { stock (bag) }\end{array}$ & Inventory \\
\hline Whole blood (WB) & 1203 & 1280 & Surplus \\
\hline Packed red cell (PRC) & 1888 & 1512 & Shortage \\
\hline Washed erythrocyte (WE) & 26 & 49 & Surplus \\
\hline Fresh frozen plasma (FFP) & 222 & 175 & Shortage \\
\hline Thrombocyte concentrate (TC) & 667 & 873 & Surplus \\
\hline Cryoprecipitate (C) & 24 & 4 & Shortage \\
\hline Apheresis (A) & 25 & 18 & Shortage \\
\hline
\end{tabular}


There were several studies related with production planning and inventory control $[4,5]$. They revealed that managing inventory able to support production activities and avoid unbalance between demand and supply on inventory. Most of study adopted this method for manufacturing case. Thus, activity of business process at Blood Transfusion Unit able to employed this method. This study aims for managing inventory on the blood component of packed red cells (PRC) in Blood Transfusion Unit in Indonesia. Furthermore, the data of blood component demand was taken from January to December 2016. This data was used to predict demand of blood component in year 2017 by looking at data history of blood component.

\section{Inventory (S)}

Managing inventory is the activity to determine the level and composition of the stock of parts, raw materials and finished products to achieve the effectively and efficiently of production and sales [6]. Moreover, managing inventory requires to implement in order to maintaining and controlling the production scheduling which it can be done by conducting forecasting demand as well as a technique of providing goods based on the amount and time as planned [7]. Furthermore, Vlckova and Patak [8] explained that forecasting activity is early step in business function that seeks to estimate demand and use of products. Thus, the production line was able to produce in the right quantity. Indeed, forecasting technique is implemented to predict future demand based on some predictor variables using historical time series data. Then, results of forecasting technique are used to perform production scheduling and control inventory.

In addition, to anticipate the unstable production activities, it need to be done arrangement of safety stock. Rădăşanu [9] stated that the safety stock is an extra supply that must be held for protection or safety in avoiding depletion of inventory. Furthermore, safety stock purpose to determine how much stock needed during the grace period to meet the demand [10]. Safety stock also was used to consider re-order point in production scheduling. Re-order point model occurs when the amount of inventory contained in the stock decreases steadily. Thus it is necessary to determine how much the minimum level of inventory should be considered so that there is no shortage of inventory. Thus, the expected amount can be calculated during the grace period. There were several models in conducting the re-order point to support production scheduling. The model was classified based on the pattern of demand rate and lead time [11]. Obviously, a Re-order point commonly referred to as a limit or a re-order point includes requests that are desired or needed during the grace period. 


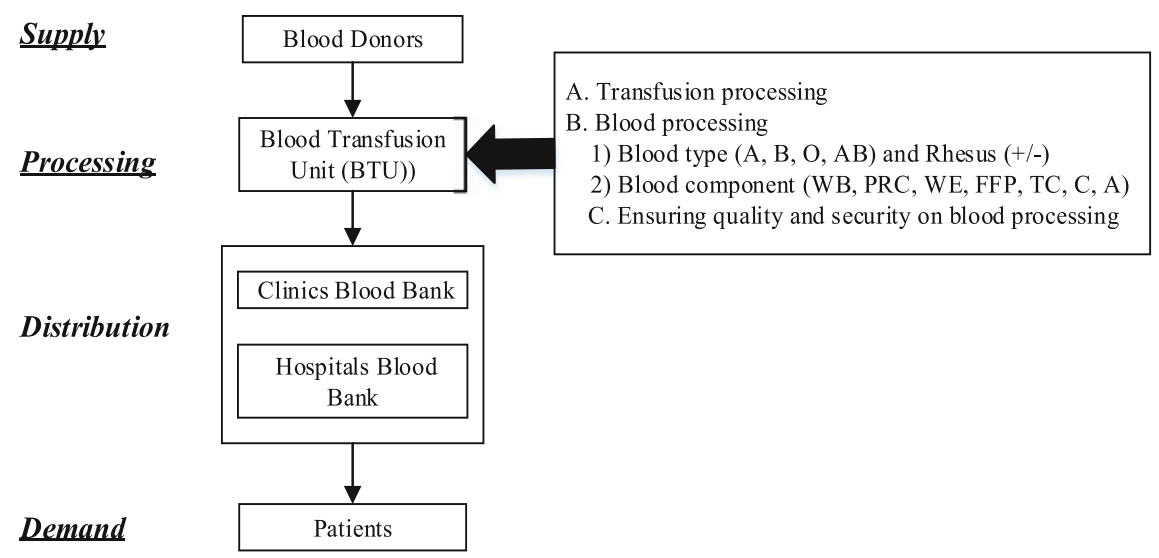

Fig. 1 Blood supply chain on Blood Transfusion Unit

\section{Blood Supply Chain}

Blood are capable of carrying oxygen $\left(\mathrm{O}_{2}\right)$ and nutrients to the tissues through flowing in the arteries, capillaries and veins and carrying carbon dioxide $\left(\mathrm{CO}_{2}\right)$ and other waste products. Moreover, Patton and Thibodeau [12] in their study described that blood consists of 4 parts including red blood cells (erythrocytes), white blood cells (leukocytes), blood platelets (thrombocytes), and blood fluid (blood plasma). Furthermore, blood can be channeled from one person to another's circulatory system due to the need for medical conditions such as trauma, surgery, shock and malfunction of red blood cell organs.

The case study of blood components demand at BTU in Indonesia was the integration of several entities into a supply chain strategy. Activity of supply chain represented of blood suppliers which they were be classified into three blood donors including permanent blood donors, blood donors volunteers, blood donors substitute. Furthermore, blood that had been transfused by donors at the Blood Transfusion Unit was used to obtain four blood types and seven blood components based on the consumer's need. Moreover, it served to obtain blood in term of safe and quality. Patients through the doctor's recommendation ordered blood through blood Bank such as Hospital and Clinic. Figure 1 shows the business activity on Blood Transfusion Unit based on blood supply chain strategy.

\section{Finding}

Managing inventory in this case study is done through several stages including forecasting demand, safety stock, and re-order point. This mechanism is used as a reference in managing blood component of the Packed Red Cell (PRC). 
Table 2 forecasting demand of Packed Red Cell using exponential smoothing with $\alpha=0.95$

\begin{tabular}{l|c|c}
\hline Month & Demand (bag) & Forecasting (bag) \\
\hline January & 1888 & 2001 \\
\hline February & 1799 & 1894 \\
\hline March & 1956 & 1804 \\
\hline April & 1915 & 1949 \\
\hline Mei & 1877 & 1917 \\
\hline June & 1655 & 1879 \\
\hline July & 1996 & 1667 \\
\hline Augustus & 2186 & 1980 \\
\hline September & 1921 & 2176 \\
\hline October & 2041 & 1934 \\
\hline November & 2214 & 2036 \\
\hline December & 2559 & 2206 \\
\hline Total & 24,007 & 23,443 \\
\hline
\end{tabular}

\section{- Forecasting}

Calculation of forecasting demand on blood component of the Packed Red Cell $(P R C)$ is initial stages in the managing inventory. This study used four methods in forecasting demand involving moving average, weighted moving average, exponential smoothing and exponential smoothing with trend. To select the appropriate forecasting method, it is determined with selecting the smallest error accuracy of each forecasting model. Then, it done verification forecasting within the control limit by using tracking signal. Moreover, positive tracking signal showed that actual value is greater than forecast, while negative value indicated actual value is less than predicted. Rangkuti [11] revealed that the best tracking signal whenever it had a low running sum of forecast error (RSFE) value or approximates the number zero. The results of this study was obtained that exponential smoothing with $\alpha=0.95$ to the best forecasting method. Thus, results of forecasting demand from the selected method will be estimated data of the blood component of Packed Red Cell (PRC) for year 2017. Table 2 is the result of forecasting blood component demand for the Packed Red Cell (PRC). Furthermore, data from result of forecasting taken place into graphic. Figure 2 is trend data of demand and forecasting on Packed Red Cell (PRC). Obviously, the data of blood component of Packed Red Cell in form of time series analysis into cyclic pattern.

- Safety Stock and Re-order Point

Calculation of safety stock and re-order point in this study was done based on several regulations related in blood donor. The policy of Ministry of Health in Indonesian revealed that blood donation is limited on 3 months for each donor [13]. Furthermore, World Health Organization (2014) also concluded that 3 month to be constraint for blood donor. Thus, this study decided lead time for blood donor during 3 months 


\section{Demand 2016 and forecasting 2017 Packed Red Cell}

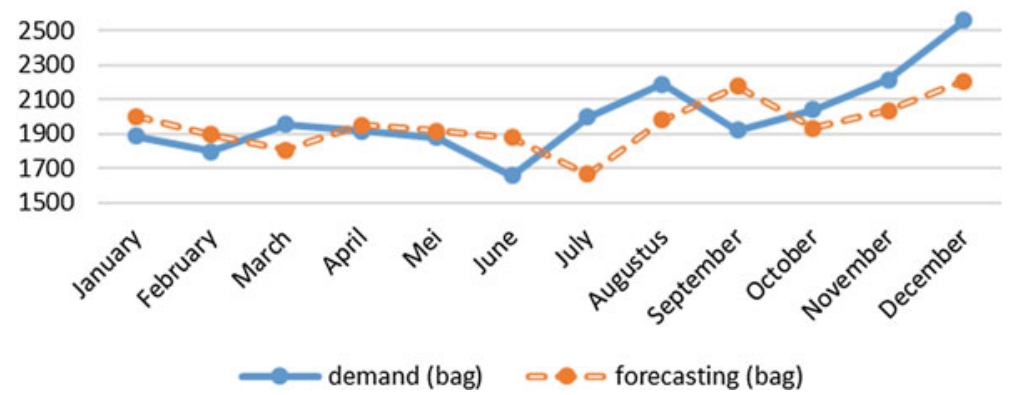

Fig. 2 Trend data of demand and forecasting on Packed Red Cell (PRC)

which it was assumed as constant lead time. Moreover, requirement of blood component of Packed Red Cell (PRD) for each month during one year changes greatly according to the patient's request. Thus, according to Rangkuti [11] who research related with strategy for managing inventory concluded that the above problem able to solve using a safety stock model that adopted variable demand rate with constant lead time.

This study required safety stock model to avoid the occurrence of lack of blood components of Packed Red Cell (PRC) in activities of business process in Blood Transfusion Unit. Then, it was continued to calculate re-oder point method to determine the minimum number of blood component for re-ordering. To determine the amount of safety stock, this agency established a risk of running out of inventory for this blood component of the by 5\%. In other words, the blood component demand of Packed Red Cell (PRC) able to meet customer requirement was 95\%. Thus, the standard deviation $(\mathrm{Z})$ was used approximately 1.65. Moreover, lead time was used by policy by Ministry Of Heath Indonesia involving 4 month (0.021). Finally, Result of safety stock for Packed Red Cell (PRC) found 34 bags. Then, the calculation of re-order point for blood component on Packed Red Cell (PRC) found 76 bags.

- Managing Inventory

The current conditions showed that blood component of Packed Red Cell (PRC) tend to change due to uncertainty of demand which it was caused by a few people to do blood donation. Thus, Blood Transfusion Unit must consider to establish the safety stock of inventory in order to maintain occurring the lack of supplies of blood component. Result of this study showed that the number of safety stock for Packed Red Cell (PRC) was 34 bags and the number of re-order point was bags 76 . This implication described that the inventory must has arrived at Blood Transfusion Unit on this number of 76 bags. Then, this agency prepared for making the reservations again. Figure 3 is strategy for managing inventory on blood supply chain to Packed Red Cell (PRC). 


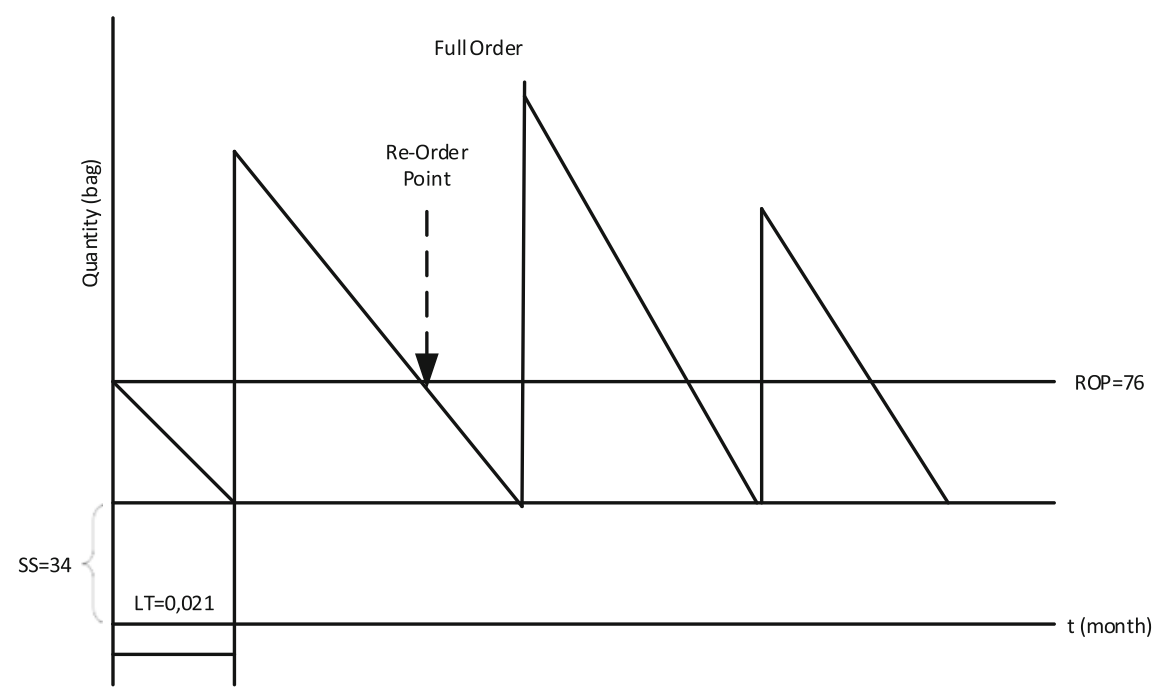

Fig. 3 Managing Inventory for Packed Red Cell (PRC)

\section{Discussion}

Blood Transfusion Unit must consider for managing inventory for blood supply chain. This research has done managing inventory through forecasting demand and re-order point which it also considered the schedule of order blood component based on the safety stock approach. This serve to arrange the production scheduling of blood components of based on when orders must be received and how many safety stocks should be provided. Especially for blood component of Packed Red Cell (PRC), there was threat for Blood Transfusion Unit whenever they do not notice this inventory. This blood component cannot be found if there are patients who desperately need blood. This is fatal for the patient because this blood component required for medical condition in form of accident and give birth which they need to do blood transfusion soon. In addition, shortage of inventory must be avoided by Blood Transfusion Unit and they also should consider viability of blood for each component. Therefore, the managing inventory for blood components is very important to maintain the inventory in this agency safely and available. Okhovat et al. [14] emphasized that irregular production schedulers able to disturb production and consumer dissatisfaction.

Moreover, there were four main entities of the blood supply chain involving donors, blood processing, hospitals and patients. They represented in supply chain relationship in form of supplier-manufacture-distributor-customer. The production process undertaken by Blood Transfusion Unit as the filtering the blood component to the patient. The results showed that the supply chain strategy in this business is still dependent on the supplier. Kähkönen [15] explained that the supplier dominant will consider their forecasting to deliver products to the buyer. Furthermore, every 
entity in the blood supply chain had different roles. Thus, the availability of blood was influenced by efficiently and effectively relationship between entities. Thus, this encouraged for balancing between supply and demand of blood inventory. Kleab [16] asserted that the balance of demand and supply can provide a competitive value for the entities involved.

\section{Conclusion and Future Work}

This study has provided managing inventory to support the blood supply chain based on consideration of forecasting demand, safety stock and re-order point. The results able to give recommendation to the Blood Transfusion Unit at Indonesia regard with the number of blood component of Packed Red Cell (PRC) provided and how much re-order to be made at the time of reaching the lead time. Furthermore, the entities in the blood supply chain in this case study consists of supplier of blood is donors. for the process of blood production, it is located in Blood Transfusion Unit as manufacture that serves as a place of blood donor, blood supply and storage. Then, the blood component is distributed to the Hospital and clinic as distribution which it is used by the patient as the customer for health purposes. Furthermore, this study limited on minimizing shortage technique and optimizing the safety stock policy. Further study is suggested to conduct simulation method in order to evaluate performance policy in managing blood inventory and prepare scenario for optimizing inventory level.

Acknowledgements The authors thank to Blood Transfusion Unit in Indonesia and Sultan Syarif Kasim State Islamic University who supported this research.

\section{References}

1. WHO, Towards $100 \%$ Voluntary Blood Donation: A Global Framework for Action, Geneva, Switzerland (2010)

2. F. Lestari, K. Ismail, A.B.A. Hamid, W. Sutopo, Designing supply chain analysis tool using SCOR model (Case study in palm oil refinery), in 2013 IEEE International Conference on Industrial Engineering and Engineering Management (IEEM), Bangkok, Thailand (2013), pp. 919-923

3. F. Lestari, U. Anwar, N. Nugraha, B. Azwar, Forecasting demand in blood supply chain (Case study on blood transfusion unit), in Lecture Notes in Engineering and Computer Science: Proceedings of The World Congress on Engineering 2017, 5-7 July 2017, London, U.K. (2017), pp. $764-767$

4. P. Wanke, A conceptual framework for inventory management: focusing on low-consumption items. Prod. Inventory Manag. J. 49(1), 6-23 (2014)

5. P. Vrat, Basic concepts in inventory management, in Materials Management: An Integrated Systems Approach (Springer, India, 2014), pp. 21-36

6. K.B. Prempeh, The impact of efficient inventory management on profitability: evidence from selected manufacturing firms in Ghana. MPRA 1-6 (2015) 
7. N. Liu, S. Ren, T. Choi, C. Hui, S. Ng, Sales forecasting for fashion retailing service industry: a review. Math. Probl. Eng. 2013, 1-10 (2013)

8. V. Vlckova, M. Patak, Role of demand planning in business process management, in 6th International Scientific Conference, 13-14 May 2010, Vilnius, Lithuania (2010), pp. 1119-1126

9. A.C. Rădăşanu, Inventory management, service level and safety. J. Public Admin. Finance Law Inventory 9, 145-153 (2016)

10. C. Mekel, P.T. Bank, C. Asia, L. Lahindah, Stock out analysis: an empirical study on forecasting, re-order point and safety stock level at PT. Combiphar, Indonesia. Rev. Integr. Bus. Econ. Res. 3(1), 52-64 (2014)

11. F. Rangkuti, Inventory Management, vol. 2 (RajaGrafindo Persada, Jakarta, 2007)

12. K.T. Patton, G.A. Thibodeau, Anatomy and Physiology, 8th edn. (Elsevier Health Sciences, 2014)

13. Ministry of Health Indonesia, Standard of Blood Transfusion Unit: Regulation No. 91, 2015 (2015)

14. M.A. Okhovat, M. Khairol, A. Mohd, T. Nehzati, Development of world class manufacturing framework by using six-sigma, total productive maintenance and lean. Sci. Res. Essays 7(50), 4230-4241 (2012)

15. A.-K. Kähkönen, The influence of power position on the depth of collaboration. Supply Chain Manag.: Int. J. 19(1), 17-30 (2014)

16. K. Kleab, Important of supply chain management. Int. J. Sci. Res. Publ. 7(9), 397-400 (2017) 